Article

\title{
Evaluation of the Antioxidant Activity of the Marine Pyrroloiminoquinone Makaluvamines
}

\author{
Eva Alonso ${ }^{1,+}{ }^{,}$Rebeca Alvariño ${ }^{1,+}$, Marta Leirós ${ }^{1}$, Jioji N. Tabudravu ${ }^{2}$, Klaus Feussner ${ }^{3}$, \\ Miriam A. Dam ${ }^{2}$, Mostafa E. Rateb ${ }^{2}$, Marcel Jaspars ${ }^{2}$ and Luis M. Botana ${ }^{1, *}$ \\ 1 Departamento de Farmacología, Facultad de Veterinaria, Universidad de Santiago de Compostela, \\ Lugo 27002, Spain; eva.alonso@usc.es (E.A.); rebeca.alvarino@usc.es (R.A.); marta.leiros@usc.es (M.L.) \\ 2 Marine Biodiscovery Centre, Department of Chemistry, University of Aberdeen, MestonWalk, \\ Aberdeen AB24 3UE, UK; j.tabudravu@abdn.ac.uk (J.N.T.); miriam.dam@abdn.ac.uk (M.A.D.); \\ Mostafa.rateb@uws.ac.uk (M.E.R.); m.jaspars@abdn.ac.uk (M.J.) \\ 3 Institute of Applied Sciences, University of the South Pacific, P.O. Box 1168, Suva, Fiji; Feussner_k@usp.ac.fj \\ * Correspondence: luis.botana@usc.es; Tel.: +34-982-822-233 \\ + These authors contributed equally to this work.
}

Academic Editor: Kirsten Benkendorff

Received: 26 September 2016; Accepted: 20 October 2016; Published: 27 October 2016

\begin{abstract}
Makaluvamines are pyrroloiminoquinones isolated from Zyzzya sponges. Until now, they have been described as topoisomerase II inhibitors with cytotoxic effects in diverse tumor cell lines. In the present work, seven makaluvamines were tested in several antioxidant assays in primary cortical neurons and neuroblastoma cells. Among the alkaloids studied, makaluvamine J was the most active in all the assays. This compound was able to reduce the mitochondrial damage elicited by the well-known stressor $\mathrm{H}_{2} \mathrm{O}_{2}$. The antioxidant properties of makaluvamine $\mathrm{J}$ are related to an improvement of the endogenous antioxidant defenses of glutathione and catalase. SHSY5Y assays proved that this compound acts as a Nrf2 activator leading to an improvement of antioxidant defenses. A low concentration of $10 \mathrm{nM}$ is able to reduce the reactive oxygen species release and maintain a correct mitochondrial function. Based on these results, non-substituted nitrogen in the pyrrole plus the presence of a $p$-hydroxystyryl without a double bond seems to be the most active structure with a complete antioxidant effect in neuronal cells.
\end{abstract}

Keywords: makaluvamine; Zyzzya; oxidative stress; neurons; marine sponge; nrf2

\section{Introduction}

Nowadays, the search for new and interesting compounds for drug development is focused on the marine environment as a source of new structures. Marine alkaloids isolated from sponges supply a wide range of new molecules to pharmaceutical libraries with different mechanisms of action [1]. These molecules have been mainly studied as anti-tumor or anti-infective agents and some of them, such as trabectedin or ziconotide, have successfully reached the pharmaceutical market [2]. One explanation for this wide range of different molecules is the fact that these organisms are usually sessile or have slow movements that restrict their own defense and therefore, they have to produce molecules to protect themselves from predators and/or bacteria overgrowth. Moreover, these molecules are often highly effective due to the marine environment where they are released [3]. The stressful conditions of the marine habitat such as ultraviolet radiation, desiccation, or metal exposure, lead to Reactive Oxygen Species (ROS) generation. Then, antioxidant agents are often isolated from marine organisms that produce them in order to counteract this oxidative stress condition [4,5]. Natural antioxidants can act exogenously, as direct scavengers, or endogenously to improve the cellular response to stress. Most of the marine antioxidants screened are crude extracts 
tested in solution-based chemical assays, but living cell assays with isolated compounds are essential for the advance to pharmacological testing [6].

In human cells, oxidative stress is involved in several pathologies such as cancer, ageing, or neurodegenerative diseases. Oxidative stress is defined as the imbalance between antioxidants and oxidants where the cellular defenses are not able to neutralize ROS overproduction. In physiological conditions, ROS are produced as a result of numerous reductions and reactions in the normal cellular operation; however, the organism has effective mechanisms to maintain a correct balance. In some situations, ROS production is increased and the cellular defenses are not able to control the equilibrium leading to oxidative damage in essential components such as lipids, proteins, and DNA, and finally to cell dysfunction and death. Among the antioxidant enzymes and proteins are superoxide dismutase, glutathione (GSH), and catalase that catalyze the processing of ROS to less toxic molecules. The enhancement of these antioxidant enzymes' activity is a pursued strategy to decrease ROS levels, restore the balance, and protect the cells [7-9].

This unbalanced oxidative condition plays an important role in neurodegenerative diseases such as Alzheimer's disease because the brain is the main consumer of oxygen and neurons are relatively sensitive to oxidative stress because of their poor antioxidant defenses [10], which makes neuronal cells a great model for antioxidant activity assays.

Makaluvamines (Figure 1) are marine metabolites mainly isolated from Zyzzya genus sponges [11,12]. This group of compounds, along with epinardins, batzellines, or discorhabdins, share a pyrroloiminoquinone ring system. The makaluvamine family is made up of several compounds with a common 7-amino substituted pyrroloiminoquinone skeleton in which substitutions at N-1, N-5, and N-9 are usual [13]. These alkaloids have been widely reported as potent cytotoxic agents in several tumor cell lines through the inhibition of DNA processing enzymes, as topoisomerase II inhibition [14-16], however no clinical trials in humans have been performed so far. Although cytotoxicity and proapoptotic tests have been extensively published, little information has been released about the antioxidant potential of makaluvamines. To our knowledge, five makaluvamines were tested in a non-cell assay at high concentrations [17], but no living cell assays have been published. In the present work, the antioxidant potential of seven makaluvamines are tested in a mouse and a human neuronal model.

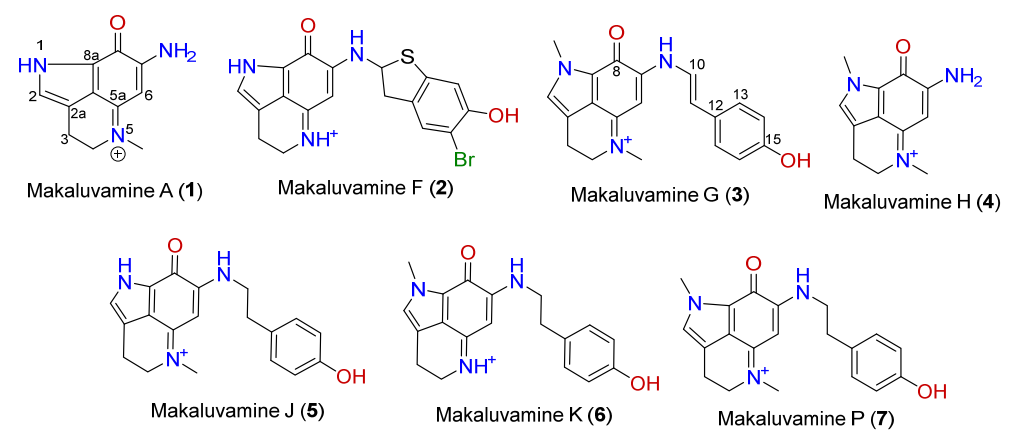

Figure 1. Chemical structures of makaluvamines.

\section{Results}

Firstly, the effect of these compounds on the cellular viability of primary cortical neurons was checked with the 3-(4,5-Dimethylthiazol-2-yl)-2,5-Diphenyltetrazolium Bromide (MTT) test. For this, three concentrations $(0.01,0.1$, and $1 \mu \mathrm{M})$ of each compound were added to the cellular medium and incubated for $24 \mathrm{~h}$. Among the 7 makaluvamines tested, only compounds $\mathbf{2}$ and $\mathbf{5}$ elicited a viability decrease. Compound 2 at $1 \mu \mathrm{M}$ was the most potent with a reduction of $54.5 \pm 20.8 \%(p=0.005) \mathrm{vs}$. control cells, whereas in the presence of compound $5(1 \mu \mathrm{M})$ the viability diminished $31.8 \pm 10.1 \%$ $(p=0.003)$ (Figure 2). In view of these results, compounds 2 and 5 were studied in all the assays at 0.05 and $0.1 \mu \mathrm{M}$, whereas all the other non-toxic compounds were tested at 0.1 and $1 \mu \mathrm{M}$. 


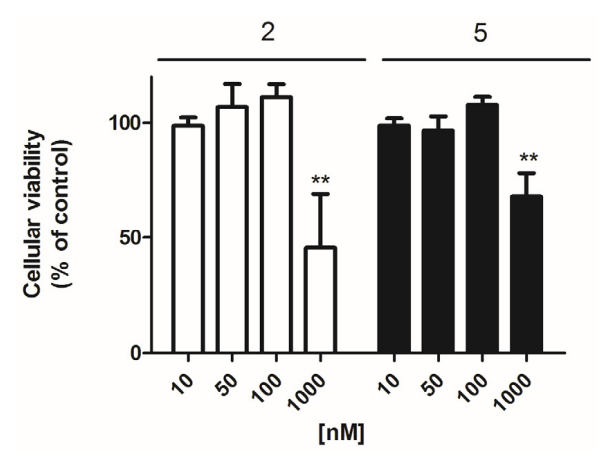

Figure 2. Effect of makaluvamines 2 and 5 on cellular viability. Cytotoxicity effect of compounds 2 and 5 after $24 \mathrm{~h}$ incubation measured by the 3-(4,5-Dimethylthiazol-2-yl)-2,5-Diphenyltetrazolium Bromide (MTT) test. ${ }^{* *} p<0.01$.

To evaluate the antioxidant potential of this compound family in this cellular model, $\mathrm{H}_{2} \mathrm{O}_{2}$ was used as an oxidative stress inductor. A $12 \mathrm{~h}$ cell incubation with $200 \mu \mathrm{M} \mathrm{H}_{2} \mathrm{O}_{2}$ produced cellular damage that resulted in a mitochondrial function decrease of $31.2 \pm 2 \%(p=0.005)$ versus non treated cells (Figure 3A) measured by the MTT test. The presence of compounds 4 or $\mathbf{5}$ was able to reduce this decrease by $15.5 \pm 8.4 \%$ and $10.3 \pm 8.7 \%$ (compound $4,0.1$ and $1 \mu \mathrm{M}, p=0.03$ ) or by $10.7 \pm 9 \%(p=0.01$ ) (compound 5 at $0.05 \mu \mathrm{M}$ ). Interestingly, when the mitochondrial potential $(\Delta \Psi \mathrm{m})$ was evaluated by tetramethylrhodamine (TMRM) assay, only compound 5 showed some effect. Compound 5 at the highest concentration tested $(0.1 \mu \mathrm{M})$ reduced the decrease of the $\Delta \Psi \mathrm{m}$ observed in the presence of $\mathrm{H}_{2} \mathrm{O}_{2}\left(\mathrm{H}_{2} \mathrm{O}_{2}, 33.6 \pm 2.5 \%, p=0.0003\right.$ and compound $\left.5,15.5 \pm 1.5 \%, p=0.012\right)$ (Figure 3B).

A

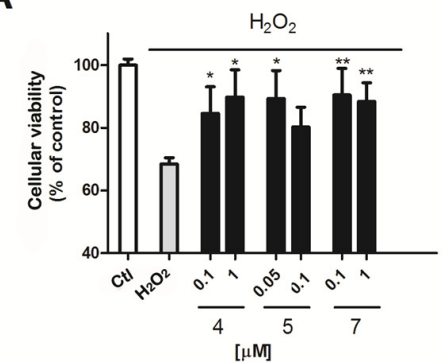

B

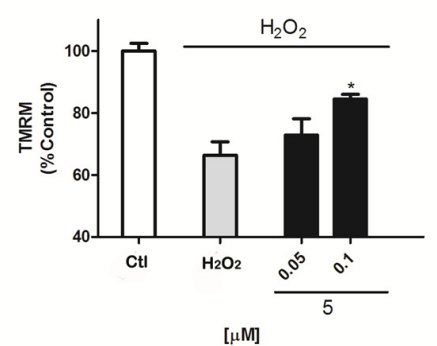

C

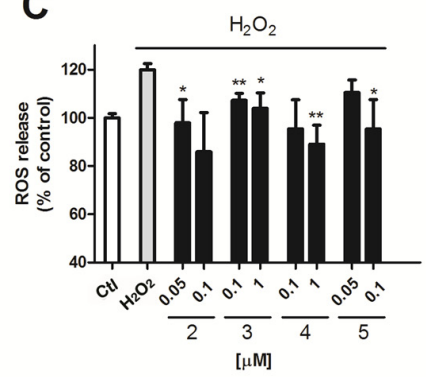

Figure 3. Effect of makaluvamines over $\mathrm{H}_{2} \mathrm{O}_{2}$ toxicity and ROS release (A) Neuroprotective effect of compound 4 and 5 in the presence of $200 \mu \mathrm{M} \mathrm{H}_{2} \mathrm{O}_{2}$ after $12 \mathrm{~h}$ incubation; (B) Effect of Compound 5 co-incubation over $\Delta \Psi \mathrm{m}$ measured by tetramethylrhodamine (TMRM) assay; (C) Compounds 2, 3, 4 , and 5 at $\mu \mathrm{M}$ concentrations $(0.05,0.1$ and $1 \mu \mathrm{M})$ inhibited ROS release versus $\mathrm{H}_{2} \mathrm{O}_{2}$ treated cells. The values are presented in percentage versus non-treated control cells, but the statistical comparison is made versus $\mathrm{H}_{2} \mathrm{O}_{2}$ treated cells. ${ }^{*} p<0.05$ and ${ }^{* *} p<0.01$. Data are mean $\pm \mathrm{SEM}$ of three or more independent experiments performed in triplicate.

Mitochondria are the main producers of ROS in the cell. The damage of this organelle can result in defective respiratory chain work that results in an excessive $\mathrm{O}_{2}$ production [18,19]. So, we next studied if some of the makaluvamines were able to reduce the ROS levels elicited by $200 \mu \mathrm{M} \mathrm{H}_{2} \mathrm{O}_{2}$ in cortical neurons. As can be seen in Figure 3C, the oxidant produced an increase in ROS levels of $121.5 \pm 2.5 \%, p=0.0001$ versus non treated cells. The presence of compounds $\mathbf{2}-\mathbf{5}$ diminished this increase. Compound 2 was effective at the two concentrations tested, reducing ROS levels in $\mathrm{H}_{2} \mathrm{O}_{2}$ treated cells by $97.9 \pm 9.6 \%$ and by $85.9 \pm 16.3 \%$ at 0.05 and $0.1 \mu \mathrm{M}$, respectively ( $p=0.03$ and 0.04 ). Compound 3 decreased ROS release in the presence of $\mathrm{H}_{2} \mathrm{O}_{2}$ to a $107.2 \pm 2.9 \%$ and to a $103.9 \pm 6.4 \%$ ( 0.1 and $1 \mu \mathrm{M}$ respectively, $p=0.008$ and 0.03 ). Compound 4 showed a ROS quantification of $95.5 \pm 5.3 \%$ 
( $1 \mu \mathrm{M}, p=0.001)$ compared with the $\sim 120 \%$ increase in the presence of the oxidant alone. Finally, compound 5 was only active at $0.1 \mu \mathrm{M}$ with ROS levels of $95.3 \pm 12.3 \%(p=0.04)$ (Figure 3C).

Antioxidants usually work as reactive species scavengers or as promoters or enhancers of the cellular antioxidant protection. GSH and Catalase are some of the main antioxidant defenses in the cell $[20,21]$, therefore, the next step was to evaluate if makaluvamines were able to improve the operation of these two antioxidants in the murine model (Figure 4). In the presence of $\mathrm{H}_{2} \mathrm{O}_{2}, \mathrm{GSH}$ activity was reduced by $25.8 \pm 3.1 \%(p=0.0003)$ versus control cells. Compound 5 decreased this inhibition, with a GSH activity of near control levels, $93.5 \pm 6.9 \%$ and $99.4 \pm 7.9 \%$, at 0.05 and $0.1 \mu \mathrm{M}$ ( $p=0.01$ and 0.02), respectively. The presence of Compound 4 also had some effect on GSH activity, but only at $0.1 \mu \mathrm{M}$ with GSH levels of $90.3 \pm 6.6 \%(p=0.04)$ (Figure $4 \mathrm{~A}$ ).

Catalase activity was affected by $\mathrm{H}_{2} \mathrm{O}_{2}$ treatment as well, as can be observed in Figure 4B; its activity was reduced by $24.4 \pm 5.5 \%(p=0.005)$ versus non treated cells. Compound 5 exhibited activity again, showing normal catalase activity levels; $101.6 \pm 8 \%(p=0.03)$ at the highest concentration $0.1 \mu \mathrm{M}$.

A

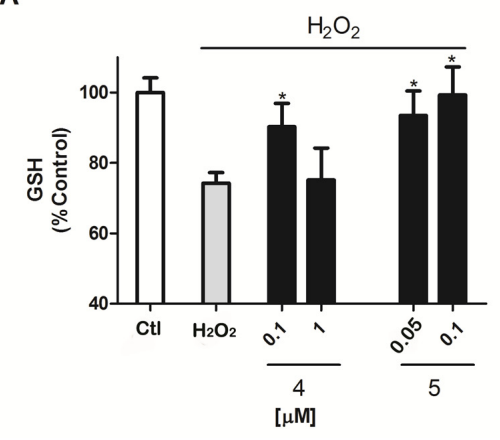

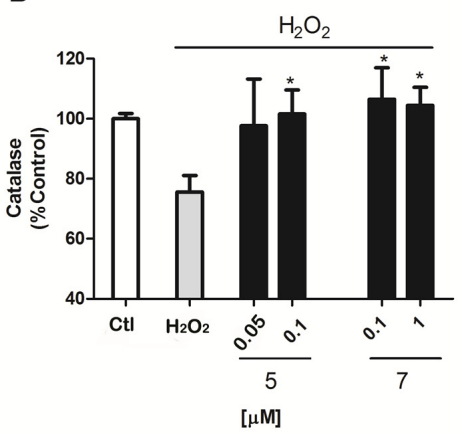

Figure 4. Evaluation of GSH and catalase activity after $12 \mathrm{~h}$ incubation with $200 \mu \mathrm{M} \mathrm{H}_{2} \mathrm{O}_{2}$. (A) Co-incubation of cells with compounds 4 and 5 at $\mu \mathrm{M}$ concentrations increase the levels measured by ThiolTracker Violet in cells co-treated with $200 \mu \mathrm{M} \mathrm{H}_{2} \mathrm{O}_{2}$ and compounds for $12 \mathrm{~h}$; (B) Compound 5 increases catalase activity in the presence of $200 \mu \mathrm{M} \mathrm{H}_{2} \mathrm{O}_{2}$ measured by the Catalase Amplex Red kit (Invitrogen, Carlsbad, CA, USA). The values are presented in percentage versus non-treated control cells and compared to cells treated with $200 \mu \mathrm{M} \mathrm{H}_{2} \mathrm{O}_{2}$ alone. ${ }^{*} p<0.05$. Data are mean $\pm \mathrm{SEM}$ of three or more independent experiments performed in triplicate.

Since compound $\mathbf{5}$ was the most effective one, we decided to check its effect in a human neuronal model. For this we used the neuroblastoma cellular line SHSY5Y. First, we tested the cytotoxicity of compound 5 in SHSY5Y cells by MTT assay. Cells were incubated with the compound at several concentrations $(0.01-10 \mu \mathrm{M})$ for $24 \mathrm{~h}$. Only the highest concentration $(10 \mu \mathrm{M})$ produced a decrease of $32.6 \pm 11.2 \%$ in cell viability with respect to the control cells (Figure 5A). Therefore, we used lower concentrations $(0.01,0.05,0.1,0.5$, and $1 \mu \mathrm{M})$ for the neuroprotection assays.

To determine the neuroprotective effect of the compound in SHSY5Y cells, we co-incubated the compound with $\mathrm{H}_{2} \mathrm{O}_{2}$ for $6 \mathrm{~h}[22,23]$. In all the assays, Vitamin $\mathrm{E}$ was added as a positive control in order to compare the antioxidant activity of compound 5 . After this time, the mitochondrial function in cells treated with $\mathrm{H}_{2} \mathrm{O}_{2}$ alone was significantly reduced to $66.2 \pm 7.1 \%(p=0.0005)$ vs. control cells. The co-treatment with compound 5 at $0.05,0.1$, and $0.5 \mu \mathrm{M}$ significantly protected SHSY5Y cells against oxidative damage, reaching percentages of $89.5 \pm 8.5 \%(p=0.04), 87.9 \pm 6.7 \%(p=0.03)$, and $92.6 \pm 5.6 \%(p=0.01)$, respectively (Figure 5B).

Compound 5 also displayed effects in the recovery of $\Delta \Psi$. Human neuroblastoma cells treated with $\mathrm{H}_{2} \mathrm{O}_{2}$ presented a decrease in $\Delta \Psi$ of $16.0 \pm 0.6 \%(p=0.0001)$ with respect to untreated cells (Figure $5 \mathrm{C}$ ). Compound 5 significantly improved the mitochondrial membrane depolarization 
produced by $\mathrm{H}_{2} \mathrm{O}_{2}$ at $0.01(93.7 \pm 2.9 \% ; p=0.02), 0.05(93.9 \pm 2.4 \% ; p=0.01)$ and $1 \mu \mathrm{M}(95.7 \pm 3.9 \%$; $p=0.03)$.

The potential to diminish ROS levels in these cells was also evaluated. The incubation with $\mathrm{H}_{2} \mathrm{O}_{2}$ for $6 \mathrm{~h}$ increased ROS release in $14.1 \pm 2.0 \%$ ( $p=0.0004)$ vs. control cells (Figure 5D). The treatment with compound 5 significantly decreased the levels of ROS in neuroblastoma cells at all the concentrations tested, showing percentages of $91.5 \pm 7.9 \%(p=0.03), 84.4 \pm 3.0 \%(p=0.0001), 83.0 \pm 2.2 \%(p=0.00005)$, $85.8 \pm 5.6 \%(p=0.003)$, and $91.8 \pm 10.7 \%(p=0.03)$ at $0.01,0.05,0.1,0.5$, and $1 \mu \mathrm{M}$, respectively.

Finally, we tested the ability of this compound to enhance the endogenous antioxidants GSH and catalase in SH-SY5Y human cells. GSH content was $15.1 \pm 2.2 \%(p=0.0002)$ lower in cells treated with $150 \mu \mathrm{M} \mathrm{H}_{2} \mathrm{O}_{2}$ than in control cells. As can be seen in Figure 5E, the incubation with compound 5 for $6 \mathrm{~h}$ at $0.05,0.1$, and $0.5 \mu \mathrm{M}$ was able to significantly improve GSH levels in SH-SY5Y cells, reaching a $93.9 \pm 3.6 \%(p=0.04), 94.2 \pm 3.4 \%(p=0.03)$ and $93.9 \pm 4.1 \%(p=0.04)$, respectively.

In order to determine the effect of the compound on the activity of catalase, human neuroblastoma cells were incubated with $10 \mu \mathrm{M}$ TBHP and compound 5 for $6 \mathrm{~h}$. After this time, SH-SY5Y cells treated with TBHP alone presented a decrease in catalase activity of $20.9 \pm 3.3 \%(p=0.003)$ with respect to untreated cells (Figure 5F). When compound 5 at $0.1,0.5$, and $1 \mu \mathrm{M}$ was added to the cells, the catalase activity was significantly increased reaching levels of $101.7 \pm 10.9 \%(p=0.04), 92.4 \pm 1.9 \%(p=0.02)$, and $108.2 \pm 0.2 \%(p=0.07)$.

A

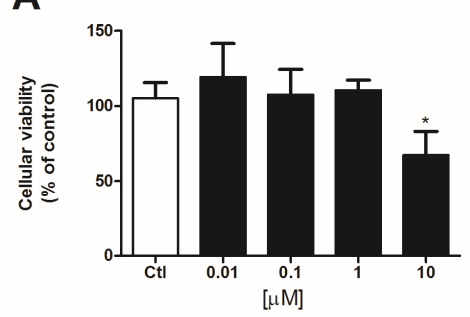

C

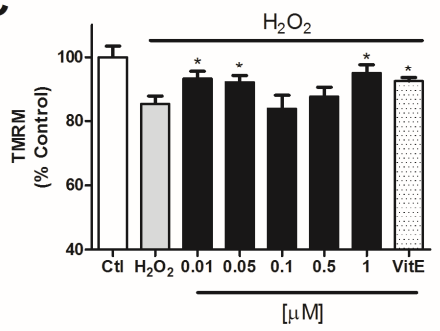

E

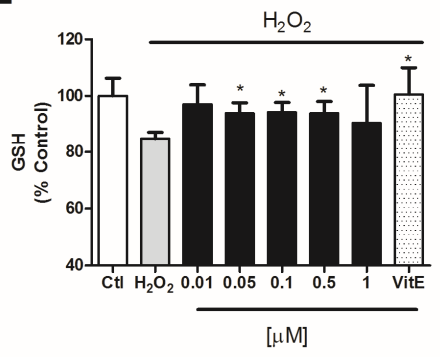

B

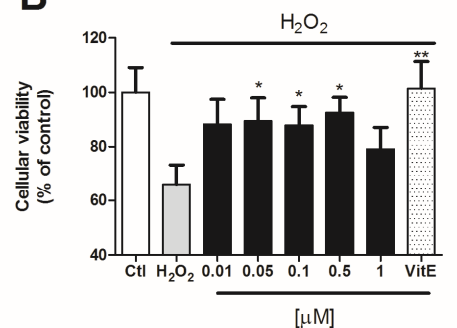

D

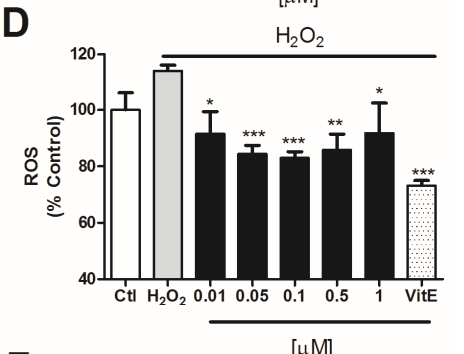

$\mathbf{F}$

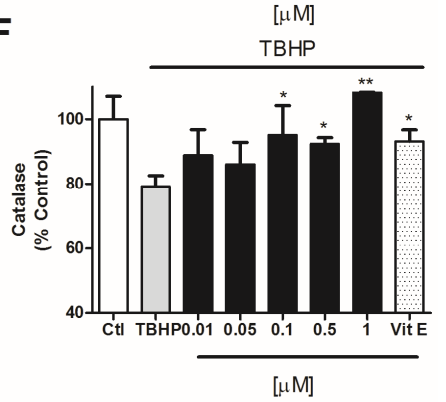

Figure 5. Makaluvamine J (5) effect over SHSY5Y cells pretreated with $\mathrm{H}_{2} \mathrm{O}_{2}$. Vitamin E was added as a positive control. (A) Cytotoxicity of compound 5 over neuroblastoma cells; (B) Neuroprotective effect of compound 5 in the presence of $150 \mu \mathrm{M} \mathrm{H}_{2} \mathrm{O}_{2}$ after $6 \mathrm{~h}$ incubation; (C) Effect of compound 5 co-incubation on $\triangle \Psi \mathrm{m}$ measured by TMRM assay; (D) Compound 5 inhibition of ROS release versus $\mathrm{H}_{2} \mathrm{O}_{2}$ treated cells; (E,F) Evaluation of GSH and catalase activity after $6 \mathrm{~h}$ incubation with $150 \mu \mathrm{M} \mathrm{H}_{2} \mathrm{O}_{2}$. GSH levels measured by ThiolTracker Violet (E) and catalase activity measured by Catalase Amplex Red kit (Invitrogen) (F). The values are presented in percentage versus non-treated control cells and compared to cells treated with $150 \mu \mathrm{M} \mathrm{H}_{2} \mathrm{O}_{2}$ alone. ${ }^{*} p<0.05$ and ${ }^{* *} p<0.01$. 
Nuclear factor (erythroid-derived2)-like 2 (Nrf2) is a transcription factor with a key role in cellular antioxidant defense. In physiological conditions this factor is bound to Kelch-like ECH associated protein 1 (KEAP1) in the cytoplasm, but under oxidative stress conditions it is released and translocated to the nucleus where it induces the expression of antioxidant genes such as catalase, superoxide dismutase, or glutathione peroxidase genes [24]. In view of the results obtained in the neuroprotection assays, the ability of compound 5 to produce the translocation of Nrf2 to the nucleus was analyzed.

Cells were treated with compound 5 at 0.05 and $0.1 \mu \mathrm{M}$ for $6 \mathrm{~h}$ and Nrf2 expression was determined by Western blot. The levels of the transcription factor in the cytosol showed no differences with respect to untreated cells, whereas nuclear levels were significantly increased by the compound presence at both concentrations (Figure 6). The treatment at $0.05 \mu \mathrm{M}$ increase Nrf2 expression by $28.9 \pm 7.8 \%(p=0.02)$ vs. control cells. At $1 \mu \mathrm{M}$, makaluvamine J enhanced the translocation of the transcription factor to $168.8 \pm 26.2 \%(p=0.04)$.

A
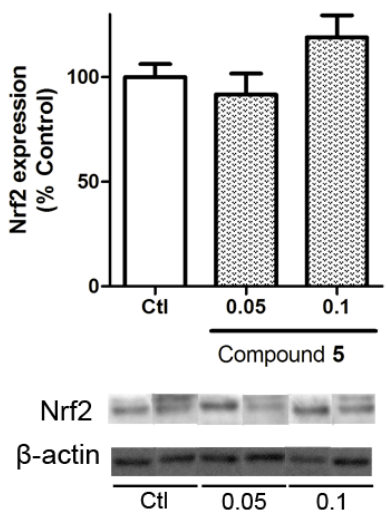

B
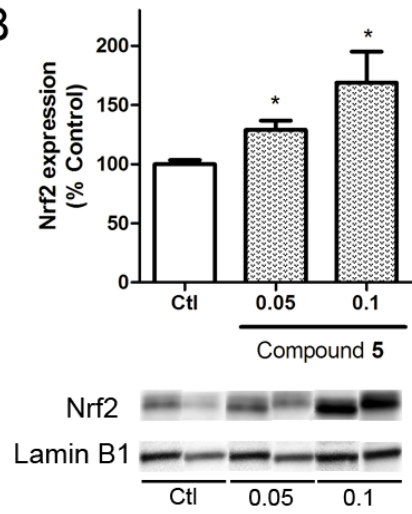

Figure 6. Induction of Nrf2 translocation by compound 5. Nrf2 levels were measured in the lysates of SHSY5Y cells incubated with the compounds for $6 \mathrm{~h}$. Results are presented separately in cytosolic (A) and nuclear (B) lysates. Nrf2 was normalized with Lamin B1 for nuclear samples and Actin for cytosolic lysates. Nuclear and cytosolic results obtained were statistically analyzed by Student's T-test and compared to the controls of the nuclear and cytosolic samples, respectively. ${ }^{*}(p<0.05)$. Data are mean \pm SEM of 3 or more independent experiments.

\section{Discussion}

In this work we characterized the effect of seven marine alkaloids isolated from Zyzyza sponge in an in vitro oxidative stress model. We used the stressor $\mathrm{H}_{2} \mathrm{O}_{2}$ to induce the oxidative stress conditions in our neuronal models [25] and therefore, induced an imbalance between ROS generation and the antioxidant defenses. Although the antioxidant potential of makaluvamines has been previously partially studied, only makaluvamine C, E, G (3), H (4), and L were tested in a non-cellular model. In these assays, their antioxidant properties were studied by a scavenging assay and by linoleic acid autooxidation, and only makaluvamine E, G (3), and L showed a moderate activity but at higher concentrations than the highest concentration tested in the present work (100 $\mu \mathrm{M}$ versus $1 \mu \mathrm{M})$ [17].

Here, we analyzed several concentrations which selection was based on the cytotoxicity results. Only compounds 2 and 5 were toxic at $1 \mu \mathrm{M}$ in the mice cortical neurons and therefore these two compounds were tested at 0.05 and $0.1 \mu \mathrm{M}$ instead of 0.1 and $1 \mu \mathrm{M}$ to guarantee that the observed effects were not related to necrotic or apoptotic events. Compound 1 was completely inactive, whereas compounds $\mathbf{6}$ and $\mathbf{7}$ showed little activity regarding cellular viability and catalase respectively. Compounds $\mathbf{2}$ and $\mathbf{3}$ were only able to reduce ROS levels, without any improvement in mitochondria function or in the antioxidant enzyme activity. This highlights that this isolated result can be related to a direct scavenger action and not with an endogenous effect, in agreement with the previous data in non-cellular systems of compound 3 [17]. 
Utkina et al. [17] showed that compound 4 was inactive in their scavenging assays whereas compound 3 and makaluvamine L elicited a moderate activity at $100 \mu \mathrm{M}$. Compounds 3 and 4 showed some activity in our antioxidant assays in primary cortical neurons, but neither of them provided full neuroprotection as compound $\mathbf{5}$ did. Compound 5 was, among the 7 makaluvamines tested, the only one that protected the mitochondria with the recovery of its potential and the reduction of ROS release. These effects were not a direct action over the oxidant species since the presence of this compound in the cellular medium showed an obvious improvement of the activity of catalase and GSH, two molecules that constituted an important cellular defense. Moreover, we tested if the effect of this compound was reproduced in the human neuroblastoma cell line SHSY5Y and we observed that after treatment this compound was also able to protect the cells from $\mathrm{H}_{2} \mathrm{O}_{2}$ damage and that this effect was related to Nrf2 factor translocation to the nucleus and endogenous antioxidant enzyme enhancement, proving the results in murine cells.

If we focus on the structure, it can be observed that the most active compound, compound 5 , and the poorly active compound 7 are almost identical. Both compounds share a p-hydroxyphenethyl unit with an aromatic ring and the only difference is the presence of a pyrrole with a non-substituted nitrogen in the case of compound 5 and a pyrrole with a $N$-methyl in the case of compound 7. This non-substituted nitrogen seems to be essential for the activity since the compounds $\mathbf{1}, \mathbf{3}, \mathbf{6}$, and $\mathbf{7}$ that shared the methyl substitution are all practically inactive or have little effect. An exception was observed in the case of compound 4, one of the simplest structures, a pyrroloiminoquinone without the p-hydroxyphenethyl unit. Although this compound presented the methyl substitution, it possessed an amine instead of the hydroxyphenethyl which could be responsible for the observed activity. However, it is noteworthy that compound $\mathbf{1}$ did not exert any activity and in this case the only difference is that compound 4 possesses a positive charged nitrogen in position 5 (Figures 1 and 7).
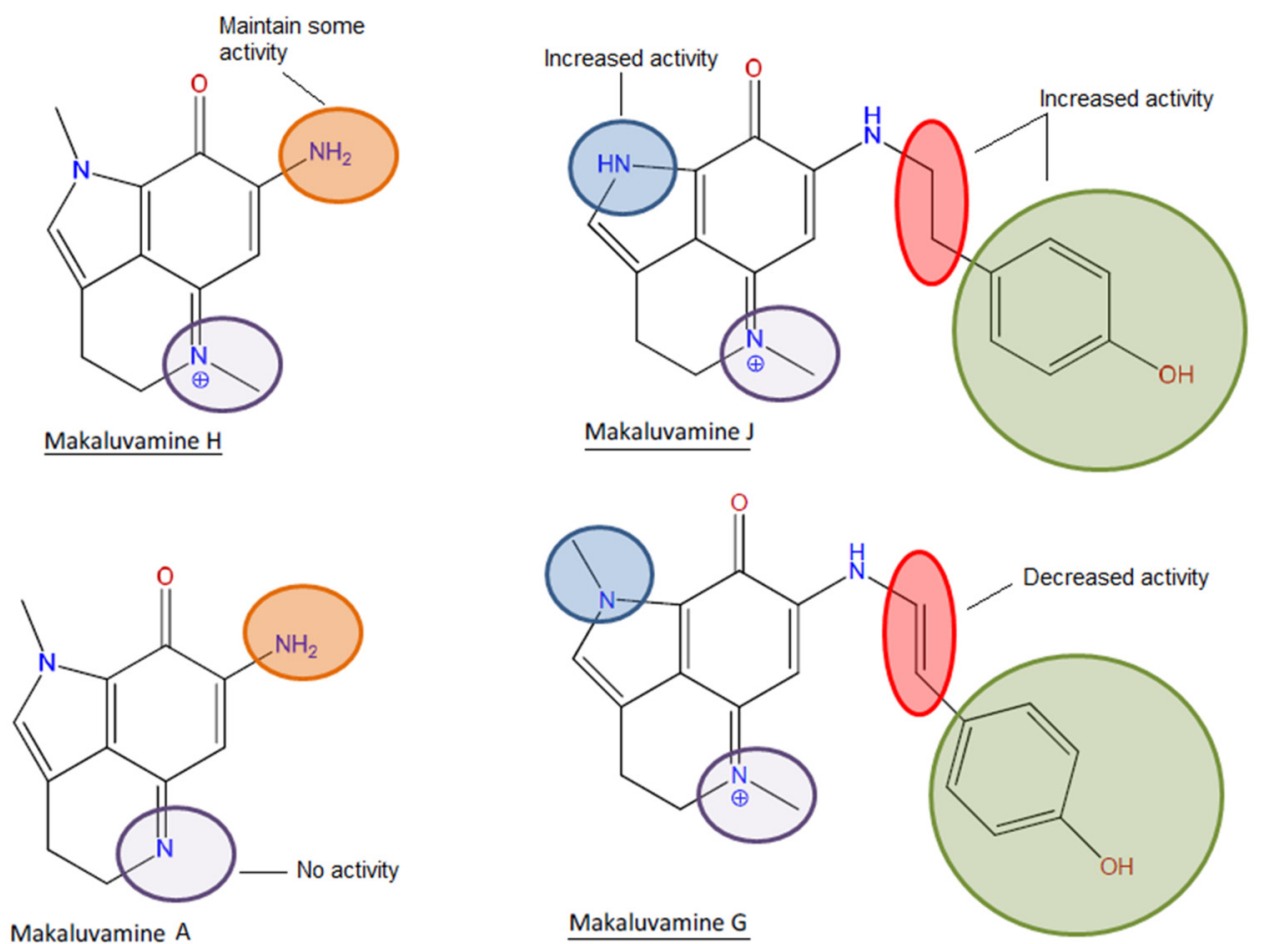

Makaluvamine A

Makaluvamine G

Figure 7. Structure-activity relationship of makaluvamines in antioxidant assays.

It was previously described in the ABTS assay that the presence of a p-hydroxystyryl unit instead of the p-hydroxyphenethyl was responsible for the scavenging activity of makaluvamine G (3) and L. In the present work, it is highlighted that although the presence of p-hydroxystyryl is not indispensable, 
the combination of this motif with the amine and the absence of a double bond produces the most complete antioxidant activity. The bioactivity of an antioxidant is usually determined by its hydrogen or electron donating properties, the ability to chelate transition metal ions, or its ability to scavenge lipid peroxyl radicals. The presence of hydroxyl groups attached to aromatic ring substructures contributes to antioxidant effects through hydrogen donation. Moreover, the presence of oxo groups, such as the ketonic $\mathrm{C}=\mathrm{O}$ at position 8 in the makaluvamines, and the absence of the $\mathrm{C} 10 / \mathrm{C} 11$ double bond contributed to improving the antioxidant characteristics [26,27].

In physiological conditions, mitochondrial respiration produces ROS, but they are scavenged by the antioxidant defenses. However, in some pathological states such as stroke, Alzheimer's disease, and Parkinson's disease, these defenses fail and ROS accumulation is followed by a cascade of mitochondrial failures that ends in cellular death. Antioxidants that work through the endogenous pathway are usually more interesting than the direct scavengers in this kind of pathologies. The antioxidant responsive element (ARE) is one of the most important cellular defenses regulated by Nrf2. Therefore, the Nrf2 pathway has been extensively studied and its role in neurodegenerative diseases has been confirmed. The protective effect of Nrf2 activation has led to the development of a FDA approved drug, Tecfidera (dimethyl fumarate), Biogen Idec (Cambridge, MA, USA), for the treatment of patients with relapsing multiple sclerosis and the application of Nrf2 activators for other diseases is currently being researched [28-30]. The development of new antioxidant molecules that have effects on mitochondria and on the antioxidant enzymes can contribute to the expansion of our knowledge about the potential of antioxidant therapies in neurodegenerative diseases. Moreover, the identification of the essential structural components for this bioactivity opens new pathways for the synthesis of new and more potent analogues.

\section{Materials and Methods}

\subsection{Compound Information}

Makaluvamine $\mathrm{A}(1), \mathrm{F}(2), \mathrm{G}(3), \mathrm{H}(4), \mathrm{J}(5), \mathrm{K}(6)$, and $\mathrm{P}(7)$ were isolated from a marine sponge (Zyzzya sp.) collected near Bouma village, Taveuni Island, Cakaudrove Province, Fiji islands. Isolations and purifications were performed by HPLC and chemical dereplications were performed by LCMS and NMR methods. Chemical information and the structures of the compounds are presented in Figure 1 while LCMS was obtained using a Thermo Instruments MS system (LTQ XL/LTQ Orbitrap Discovery) coupled to a Thermo Instruments HPLC system (Accela PDA detector, Accela PDA autosampler, and Accela pump) and using a capillary voltage of $45 \mathrm{~V}$, capillary temperature of $260^{\circ} \mathrm{C}$, auxiliary gas flow rate of 10-20 arbitrary units, sheath gas flow rate of 40-50 arbitrary units, spray voltage of $4.5 \mathrm{kV}$, and a mass range of 100-2000 amu (maximum resolution 30,000). 1H NMR (obtained using Varian 400 $\mathrm{MHz}$ NMRsystem) data of all of the compounds are found in the Supplementary Materials.

\subsection{Cell Culture}

Swiss mice were used to obtain primary cultures of cortical neurons. All protocols described in this work were revised and authorized by the University of Santiago de Compostela Institutional Animal Care and Use Committee and complied with European legislation on the use and management of experimental animals.

Primary cortical neurons were obtained from 15 to 18 day old mice fetuses as described previously [31]. Briefly, the cerebral cortex was removed and neuronal cells were dissociated by trypsinization at $37^{\circ} \mathrm{C}$, followed by mechanical titration in DNase solution $(0.005 \% w / v)$ with a soybean trypsin inhibitor $(0.05 \% w / v)$. Cells were suspended in DMEM supplemented with p-amino benzoate, insulin, penicillin, and 10\% fetal serum. The cell suspension was seeded in 96 multiwell plates and incubated in a humidified $5 \% \mathrm{CO}_{2} / 95 \%$ air atmosphere at $37^{\circ} \mathrm{C}$. Cytosine arabinoside $20 \mu \mathrm{M}$, was added before the $48 \mathrm{~h}$ of culturing to prevent growth of non-neuronal cells. In all the experiments, cortical neurons were treated for $4-5$ days in vitro (div). 
The human neuroblastoma SHSY5Y cell line was purchased from American Type Culture Collection (ATCC), number CRL2266. The cells were maintained in Dulbecco's Modified Eagle's medium: Nutrient Mix F-12 (DMEM/F-12) supplemented with 10\% fetal bovine serum, glutamax, $100 \mathrm{U} / \mathrm{mL}$ penicillin, and $100 \mu \mathrm{g} / \mathrm{mL}$ streptomycin at $37^{\circ} \mathrm{C}$ in a humidified atmosphere of $5 \% \mathrm{CO}_{2}$ and $95 \%$ air. Cells were dissociated weekly using $0.05 \%$ trypsin/EDTA. All reagents were provided by Thermo Fisher Scientific (Waltham, MA, USA).

\subsection{Chemicals and Solutions}

Plastic tissue-culture dishes were purchased from Falcon (Madrid, Spain). Fetal serum and Dulbecco's Modified Eagle's medium (DMEM) were purchased from Thermo Fisher Scientific (Waltham, MA, USA). All other chemicals were reagent grade and purchased from Sigma-Aldrich (Madrid, Spain).

\subsection{Cytotoxicity Assay}

Cell viability was assessed by the MTT (3-[4,5-dimethylthiazol-2-yl]-2,5-diphenyltetrazoliumbromide) test, as previously described $[32,33]$. The assay was performed in cultures grown in 96 well plates and exposed to different compound concentrations $(0.01,0.05,0.1$ and $1 \mu \mathrm{M})$ added to the culture medium. For all the 96 well plate assays, 50,000 cells/well were seeded. Cultures were maintained in the presence of the compounds at $37{ }^{\circ} \mathrm{C}$ in humidified $5 \% \mathrm{CO}_{2} / 95 \%$ air atmosphere for $48 \mathrm{~h}$. Saponin was used as the cellular death control and its absorbance was subtracted from the other data. After treatment time, cells were rinsed and incubated for $1 \mathrm{~h}$ with a solution of MTT $(500 \mu \mathrm{g} / \mathrm{mL})$ dissolved in saline buffer. After washing off excess MTT, cells were disaggregated with 5\% sodium dodecyl sulfate and the absorbance of the colored formazan salt was measured at $595 \mathrm{~nm}$ in a spectrophotometer plate reader.

\subsection{Neuroprotection Assays}

All assays were performed in 96-well plates (50,000 cells/well), as co-incubations of $200 \mu \mathrm{M} \mathrm{H}_{2} \mathrm{O}_{2}$ and the compound in two different concentrations for $12 \mathrm{~h}$ on $4-5$ div murine cortical neurons [34]. Neuroblastoma cells were cultured instead with $150 \mu \mathrm{M}$ for $6 \mathrm{~h}[22,23]$.

Neuroprotection and Mitochondrial Membrane Potential ( $\Delta \Psi \mathrm{m})$ Assays

The neuroprotective effects on thecellular viability of Makaluvamines in the presence of the oxidant $\mathrm{H}_{2} \mathrm{O}_{2}$ were measured by the MTT test following the method described above and changes in $\Delta \Psi \mathrm{m}$ were studied with the tetramethylrhodamine methyl ester (TMRM) assay. For TMRM assays, cells were washed twice with saline solution and incubated with $1 \mu \mathrm{M}$ TMRM for $30 \mathrm{~min}$. Then neurons were solubilized with $50 \% \mathrm{DMSO} /$ water. Fluorescence values were obtained using a spectrophotometer plate reader (535 $\mathrm{nm}$ excitation, $590 \mathrm{~nm}$ emission).

\subsection{Determination of ROS Production}

Intracellular ROS levels were determined with carboxy- $\mathrm{H}_{2}$ DCFDA (5-(and-6)-carboxy-2', $7^{\prime}$ dichlorodihydrofluorescein diacetate). After treatment with Makaluvamines and $\mathrm{H}_{2} \mathrm{O}_{2}$, cells were washed twice with serum-free medium. Then, $20 \mu \mathrm{M}$ of carboxy- $\mathrm{H}_{2}$ DCFDA dissolved in serum-free medium was added to the cells. After $1 \mathrm{~h}$ at $37^{\circ} \mathrm{C}$, the medium containing the fluorescence dye was replaced with PBS. The plate was incubated for $30 \mathrm{~min}$ at $37^{\circ} \mathrm{C}$ and fluorescence was read at $527 \mathrm{~nm}$, with an excitation wavelength of $495 \mathrm{~nm}$.

\subsection{Glutathione Assay}

Reduced glutathione is the majority of intracellular free thiols in cells, so we used ThiolTracker ${ }^{\mathrm{TM}}$ Violet dye to estimating their levels in our treated cells. Neurons were washed with phosphate buffer 
solution and loaded with $10 \mu \mathrm{M}$ ThiolTracker ${ }^{\mathrm{TM}}$ Violet dye for $1 \mathrm{~h}$ at $37^{\circ} \mathrm{C}$. After incubation, neurons were washed once and fluorescence was read at $404 \mathrm{~nm}$ excitation and emission at $526 \mathrm{~nm}$.

\subsection{Catalase Activity Assay}

Catalase activity was measured with an Amplex ${ }^{\circledR}$ Red Catalase Assay Kit after exposure of the samples to $\mathrm{H}_{2} \mathrm{O}_{2}$ following the commercial protocol. Fluorescence was read at $530 \mathrm{~nm}$ excitation and $590 \mathrm{~nm}$ emission. Enzymatic activity was calculated by subtracting sample values to the no-catalase control.

SHSY5Y human neuroblastoma cells were co-incubated with $10 \mu \mathrm{M}$ tert-butyl hydroperoxide (TBHP) instead of $\mathrm{H}_{2} \mathrm{O}_{2}$ to obtain a clearer signal and makaluvamine $\mathrm{J}(0.01,0.05,0.1,0.5$, and $1 \mu \mathrm{M})$ for $6 \mathrm{~h}$.

\subsection{Western Blot Analysis}

SH-SY5Y cells were seeded in 6-well plates at a density of $1 \times 10^{6}$ cells per well and treated with makaluvamine $\mathrm{J}(0.05$ and $0.1 \mu \mathrm{M})$ for $6 \mathrm{~h}$. After treatment with the compound, neuroblastoma cells were rinsed twice with ice-cold PBS. Next, $100 \mu \mathrm{L}$ of an ice-cold hypotonic solution buffer (20 mM Tris- $\mathrm{HCl} \mathrm{pH} \mathrm{7.4,} 10 \mathrm{mM} \mathrm{NaCl}$, and $3 \mathrm{mM} \mathrm{MgCl}_{2}$, containing a complete phosphatase/protease inhibitor cocktail from Roche) were added. Cells were scrapped, incubated on ice for 15 min and finally centrifuged at $3000 \mathrm{rpm}, 4^{\circ} \mathrm{C}$ for10 min. The supernatant was collected as the cytosolic fraction and the pellet was resuspended in an ice-cold nuclear extraction buffer (100 mM Tris pH 7.4, $2 \mathrm{mM}$ $\mathrm{Na}_{3} \mathrm{VO}_{4}, 100 \mathrm{mM} \mathrm{NaCl}, 1 \%$ Triton $\mathrm{X}-100,1 \mathrm{mM}$ EDTA, 10\% glycerol, 1 mM EGTA, 0.1\% SDS, $1 \mathrm{mM} \mathrm{NaF}$, $0.5 \%$ deoxycholate, and $20 \mathrm{mM} \mathrm{Na}_{4} \mathrm{P}_{2} \mathrm{O}_{7}$, containing $1 \mathrm{mM}$ PMSF and a protease inhibitor cocktail). Samples were incubated for $30 \mathrm{~min}$, vortexedin $10 \mathrm{~min}$ intervals, and centrifuged at $14,000 \mathrm{~g}$ and $4{ }^{\circ} \mathrm{C}$ for $30 \mathrm{~min}$. The supernatant was saved for nuclear protein fraction. This fraction was quantified by the Bradford method, whereas the cytosolic protein fraction was quantified using the Direct Detect system (MerckMillipore, Darmstadt, Germany). Samples containing $20 \mu \mathrm{g}$ (cytosolic fraction) or $10 \mu \mathrm{g}$ (nuclear fraction) were used for electrophoresis, which was resolved in a 10\% sodium dodecyl sulphate polyacrylamide gel (Biorad, Hercules, CA, USA) and transferred onto PVDF membranes (Millipore). The Snap i.d. protein detection system was used for membrane blocking and antibody incubation. Anti-NF-E2 related factor 2 antibody was used to detect Nrf2 (1:1000, Millipore), and the signal was normalized using $\beta$-actin (1:10,000, Millipore) for the cytosolic fraction and laminB1 (1:1000, ABCAM) for the nuclear fraction. Protein bands were detected using Supersignal West Pico Luminiscent Substrate, Supersignal West Femto Maximum Sensitivity Substrate (Thermo Fisher Scientific), the Diversity GeneSnap system (Syngene, Cambridge, UK), and software.

\subsection{Statistical Analysis}

All the results are expressed as means \pm SEM of three or more experiments (each performed in triplicate). Statistical comparison was done by Student's $T$-test $p$ values $<0.05$ were considered statistically significant.

Supplementary Materials: The following are available online at www.mdpi.com/1660-3397/14/11/197/s1, Figure S1: MS analysis of the isolated makaluvamines, Figure S2: 1H NMR spectra of the isolated makaluvamines.

Acknowledgments: The research leading to these results received funding from the following FEDER cofounded-grants. From CDTI and Technological Funds, supported by the Ministerio de Economía y Competitividad, AGL2012-40185-CO2-01, AGL2014-58210-R, and the Consellería de Cultura, Educación e Ordenación Universitaria, GRC2013-016, and through the Axencia Galega de Innovación, Spain, ITC-20133020 SINTOX. From CDTI under ISIP Programme, Spain, IDI-20130304 APTAFOOD. From the European Union's Seventh Framework Programme managed by REA—Research Executive Agency (FP7/2007-2013) under grant agreement 312184 PHARMASEA.

Author Contributions: The manuscript was written through the contributions of all authors. Eva Alonso, Rebeca Alvariño, and Marta Leirós wrote and performed all the in vitro experiments. Jioji N. Tabudravu, Miriam A. Dam, and Mostafa E. Rateb wrote and performed all the chemical assays including the isolation 
and purification through LCMS and 1H NMR. Klaus Feussner collected all the material and Marcel Jaspars and Luis M. Botana wrote and designed the experiments. All authors have given approval to the final version of the manuscript.

Conflicts of Interest: The authors declare no conflict of interest.

\section{References}

1. Glaser, K.B.; Mayer, A.M. A renaissance in marine pharmacology: From preclinical curiosity to clinical reality. Biochem. Pharmacol. 2009, 78, 440-448. [CrossRef] [PubMed]

2. Mayer, A.M.; Glaser, K.B.; Cuevas, C.; Jacobs, R.S.; Kem, W.; Little, R.D.; McIntosh, J.M.; Newman, D.J.; Potts, B.C.; Shuster, D.E. The odyssey of marine pharmaceuticals: A current pipeline perspective. Trends Pharmacol. Sci. 2010, 31, 255-265. [CrossRef] [PubMed]

3. Rane, R.; Sahu, N.; Shah, C.; Karpoormath, R. Marine bromopyrrole alkaloids: Synthesis and diverse medicinal applications. Curr. Top. Med. Chem. 2014, 14, 253-273. [CrossRef] [PubMed]

4. Dunlap, W.C.; Shick, J.M.; Yamamoto, Y. Sunscreens, oxidative stress and antioxidant functions in marine organisms of the great barrier reef. Redox Rep. 1999, 4, 301-306. [CrossRef] [PubMed]

5. Lysek, N.; Kinscherf, R.; Claus, R.; Lindel, T. L-5-hydroxytryptophan: Antioxidant and anti-apoptotic principle of the intertidal sponge hymeniacidonheliophila. Z. Naturforsch. C 2003, 58, 568-572. [CrossRef] [PubMed]

6. Takamatsu, S.; Hodges, T.W.; Rajbhandari, I.; Gerwick, W.H.; Hamann, M.T.; Nagle, D.G. Marine natural products as novel antioxidant prototypes. J. Nat. Prod. 2003, 66, 605-608. [CrossRef] [PubMed]

7. Ajith, T.A.; Padmajanair, G. Mitochondrial pharmaceutics: A new therapeutic strategy to ameliorate oxidative stress in Alzheimer's disease. Curr. Aging Sci. 2015, 8, 235-240. [CrossRef] [PubMed]

8. Ramis, M.R.; Esteban, S.; Miralles, A.; Tan, D.X.; Reiter, R.J. Protective effects of melatonin and mitochondria-targeted antioxidants against oxidative stress: A review. Curr. Med. Chem. 2015, 22, 2690-2711. [CrossRef] [PubMed]

9. Yao, C.; Behring, J.B.; Shao, D.; Sverdlov, A.L.; Whelan, S.A.; Elezaby, A.; Yin, X.; Siwik, D.A.; Seta, F.; Costello, C.E.; et al. Overexpression of catalase diminishes oxidative cysteine modifications of cardiac proteins. PLoS ONE 2015, 10, e0144025. [CrossRef] [PubMed]

10. Emerit, J.; Edeas, M.; Bricaire, F. Neurodegenerative diseases and oxidative stress. Biomed. Pharmacother. 2004, 58, 39-46. [CrossRef] [PubMed]

11. Barrows, L.R.; Radisky, D.C.; Copp, B.R.; Swaffar, D.S.; Kramer, R.A.; Warters, R.L.; Ireland, C.M. Makaluvamines, marine natural products, are active anti-cancer agents and DNA topo II inhibitors. Anticancer Drug Des. 1993, 8, 333-347. [PubMed]

12. Casapullo, A.; Cutignano, A.; Bruno, I.; Bifulco, G.; Debitus, C.; Gomez-Paloma, L.; Riccio, R. Makaluvamine p, a new cytotoxic pyrroloiminoquinone from zyzzya cf. Fuliginosa. J. Nat. Prod. 2001, 64, 1354-1356. [CrossRef] [PubMed]

13. Antunes, E.M.; Copp, B.R.; Davies-Coleman, M.T.; Samaai, T. Pyrroloiminoquinone and related metabolites from marine sponges. Nat. Prod. Rep. 2005, 22, 62-72. [CrossRef] [PubMed]

14. Boucle, S.; Melin, C.; Clastre, M.; Guillard, J. Design, synthesis and evaluation of new marine alkaloid-derived pentacyclic structures with anti-tumoral potency. Mar. Drugs 2015, 13, 655-665. [CrossRef] [PubMed]

15. Matsumoto, S.S.; Haughey, H.M.; Schmehl, D.M.; Venables, D.A.; Ireland, C.M.; Holden, J.A.; Barrows, L.R. Makaluvamines vary in ability to induce dose-dependent DNA cleavage via topoisomerase II interaction. Anticancer Drugs 1999, 10, 39-45. [CrossRef] [PubMed]

16. Shinkre, B.A.; Raisch, K.P.; Fan, L.; Velu, S.E. Analogs of the marine alkaloid makaluvamines: Synthesis, topoisomerase II inhibition, and anticancer activity. Bioorg. Med. Chem. Lett. 2007, 17, 2890-2893. [CrossRef] [PubMed]

17. Utkina, N.K. Antioxidant activity of zyzzyanones and makaluvamines from the marine sponge Zyzzya fuliginosa. Nat. Prod. Commun. 2013, 8, 1551-1552. [PubMed]

18. Chaturvedi, R.K.; Flint Beal, M. Mitochondrial diseases of the brain. Free Radic. Biol. Med. 2013, 63, 1-29. [CrossRef] [PubMed]

19. Liochev, S.I. Reactive oxygen species and the free radical theory of aging. Free Radic. Biol. Med. 2013, 60, 1-4. [CrossRef] [PubMed] 
20. Cacciatore, I.; Baldassarre, L.; Fornasari, E.; Mollica, A.; Pinnen, F. Recent advances in the treatment of neurodegenerative diseases based on GSH delivery systems. Oxid. Med. Cell. Longev. 2012, 2012, 240146. [CrossRef] [PubMed]

21. Melo, A.; Monteiro, L.; Lima, R.M.; Oliveira, D.M.; Cerqueira, M.D.; El-Bacha, R.S. Oxidative stress in neurodegenerative diseases: Mechanisms and therapeutic perspectives. Oxid. Med. Cell. Longev. 2011, 2011, 467180. [CrossRef] [PubMed]

22. Song, H.; Kim, W.; Choi, J.H.; Kim, S.H.; Lee, D.; Park, C.H.; Kim, S.; Kim, D.Y.; Kim, K.T. Stress-induced nuclear translocation of cdk5 suppresses neuronal death by downregulatingerk activation via vrk3 phosphorylation. Sci. Rep. 2016, 6, 28634. [CrossRef] [PubMed]

23. Yang, R.; Wei, L.; Fu, Q.Q.; Wang, H.; You, H.; Yu, H.R. Sod3 ameliorates h2o2-induced oxidative damage in sh-sy5y cells by inhibiting the mitochondrial pathway. Neurochem. Res. 2016, 41, 1818-1830. [CrossRef] [PubMed]

24. Dinkova-Kostova, A.T.; Abramov, A.Y. The emerging role of nrf2 in mitochondrial function. Free Radic. Biol. Med. 2015, 88, 179-188. [CrossRef] [PubMed]

25. Zhao, G.; Yao-Yue, C.; Qin, G.W.; Guo, L.H. Luteolin from purple perilla mitigates ros insult particularly in primary neurons. Neurobiol. Aging 2012, 33, 176-186. [CrossRef] [PubMed]

26. Aboul-Enein, H.Y.; Kruk, I.; Kladna, A.; Lichszteld, K.; Michalska, T. Scavenging effects of phenolic compounds on reactive oxygen species. Biopolymers 2007, 86, 222-230. [CrossRef] [PubMed]

27. Williams, R.J.; Spencer, J.P.; Rice-Evans, C. Flavonoids: Antioxidants or signalling molecules? Free Radic. Biol. Med. 2004, 36, 838-849. [CrossRef] [PubMed]

28. Obuobi, S.; Karatayev, S.; Chai, C.L.; Ee, P.L.; Matyus, P. The role of modulation of antioxidant enzyme systems in the treatment of neurodegenerative diseases. J. Enzym. Inhib. Med. Chem. 2016, 1-11. [CrossRef] [PubMed]

29. McBean, G.J.; Lopez, M.G.; Wallner, F.K. Redox-based therapeutics in neurodegenerative disease. Br. J. Pharmacol. 2016. [CrossRef] [PubMed]

30. Lu, M.C.; Ji, J.A.; Jiang, Z.Y.; You, Q.D. The keap1-nrf2-are pathway as a potential preventive and therapeutic target: An update. Med. Res. Rev. 2016, 36, 924-963. [CrossRef] [PubMed]

31. Vale, C.; Alonso, E.; Rubiolo, J.A.; Vieytes, M.R.; LaFerla, F.M.; Gimenez-Llort, L.; Botana, L.M. Profile for amyloid-beta and tau expression in primary cortical cultures from 3xtg-ad mice. Cell. Mol. Neurobiol. 2010, 30, 577-590. [CrossRef] [PubMed]

32. Alonso, E.; Vale, C.; Vieytes, M.R.; Laferla, F.M.; Gimenez-Llort, L.; Botana, L.M. 13-desmethyl spirolide-c is neuroprotective and reduces intracellular abeta and hyperphosphorylated tau in vitro. Neurochem. Int. 2011, 59, 1056-1065. [CrossRef] [PubMed]

33. Alonso, E.; Vale, C.; Vieytes, M.R.; Laferla, F.M.; Gimenez-Llort, L.; Botana, L.M. The cholinergic antagonist gymnodimine improves abeta and tau neuropathology in an in vitro model of alzheimer disease. Cell. Physiol. Biochem. 2011, 27, 783-794. [CrossRef] [PubMed]

34. Leiros, M.; Sanchez, J.A.; Alonso, E.; Rateb, M.E.; Houssen, W.E.; Ebel, R.; Jaspars, M.; Alfonso, A.; Botana, L.M. Spongionella secondary metabolites protect mitochondrial function in cortical neurons against oxidative stress. Mar. Drugs 2014, 12, 700-718. [CrossRef] [PubMed]

(C) 2016 by the authors; licensee MDPI, Basel, Switzerland. This article is an open access article distributed under the terms and conditions of the Creative Commons Attribution (CC-BY) license (http://creativecommons.org/licenses/by/4.0/). 